\title{
Hydrogeochemical and Groundwater Quality Studies in the High Bandama Watershed at Tortiya (Northern of Côte d'Ivoire)
}

\author{
Tanina Drissa Soro ${ }^{*}$, Gbombélé Soro² ${ }^{2}$ Kouassi Ernest Ahoussi², Yéi Marie Solange Oga ${ }^{2}$, \\ Nagnin Soro ${ }^{2}$
}

${ }^{1}$ Unit Training and Research in Environment, University Jean Lorougnon Guédé, Daloa, Ivory Coast

${ }^{2}$ Unit Training and Research in Earth Science, University Félix Houphouët Boigny, Abidjan, Ivory Coast

Email: *standriss@gmail.com

How to cite this paper: Soro, T. D., Soro, G., Ahoussi, K. E., Oga, Y. M. S., \& Soro, N. (2019). Hydrogeochemical and Groundwater Quality Studies in the High Bandama Watershed at Tortiya (Northern of Côte d'Ivoire). Journal of Geoscience and Environment Protection, 7, 49-61.

https://doi.org/10.4236/gep.2019.72004

Received: September 22, 2018

Accepted: February 12, 2019

Published: February 15, 2019

Copyright $\odot 2019$ by author(s) and Scientific Research Publishing Inc. This work is licensed under the Creative Commons Attribution International License (CC BY 4.0).

http://creativecommons.org/licenses/by/4.0/

\begin{abstract}
Hydrochemical and groundwater quality of High Bandama watershed were investigated through thirty-five (35) samples composed of boreholes, hand pump wells and traditional wells. The analysis of physico-chemical parameters shows that groundwater is acidic with $\mathrm{pH}$ ranges from 3.2 to 6.9 and mean of 5.4. Electrical conductivity (EC) values were generally low and minimum and maximum were respectively $77 \mu \mathrm{S} / \mathrm{cm}$ and $553 \mu \mathrm{S} / \mathrm{cm}$ with an average of $250.3 \mu \mathrm{S} / \mathrm{cm}$. Major cations $\left(\mathrm{Ca}^{2+}, \mathrm{Mg}^{2+}, \mathrm{Na}^{+}\right.$and $\left.\mathrm{K}^{+}\right)$were also generally low. $\mathrm{Ca}^{2+}$ and $\mathrm{Mg}^{2+}$ are being the most dominants cations with concentration values ranges from $4-56 \mathrm{mg} / \mathrm{l}$ and $0-55 \mathrm{mg} / \mathrm{l} \mathrm{respec}-$ tively with mean value of 18.11 and $15.31 \mathrm{mg} / \mathrm{l} . \mathrm{HCO}_{3}^{-}$is the most dominant anion with minimum and maximum values ranging from 5 to $215 \mathrm{mg} / \mathrm{l}$. According to WHO guidelines, groundwater quality is good for drinking. Piper diagram classified the hydrogeochemical facies into $\mathrm{Ca}-\mathrm{HCO}_{3}(48.57 \%)$, $\mathrm{Ca}-\mathrm{Mg}-\mathrm{HCO}_{3}$ (31.43\%), Ca-Mg-Cl (17.14\%) and $\mathrm{Na}-\mathrm{Cl}$ (2.86\%) water type with one sample for $\mathrm{Na}-\mathrm{Cl}$. Compositional relation with plot of $\mathrm{Ca}+\mathrm{Mg}$ versus $\mathrm{HCO}_{3}+\mathrm{SO}_{4}$ and Chloro Alkaline Indice (CAI) confirms that the majority of groundwater samples (66.67\%) exchange their ions $\mathrm{Ca}$ and $\mathrm{Mg}$ with $\mathrm{Na}$ and $\mathrm{K}$ from aquifer materials. Gibbs diagram showed that the rock-water interaction or weathering is the dominant process responsible of water chemistry.
\end{abstract}

\section{Keywords}

Groundwater, Hydrochemical Methods, Waters Types, High Bandama Watershed 


\section{Introduction}

The importance of water and particularly groundwater is not to demonstrate. Accessibility to a safe and reliable source of water is essential for sustainable development. Water may exist in quantity but if its quality is not good, it becomes unsustainable. Groundwater has become the major source of water supply for domestic, industrial and agricultural sectors of many countries (Ghislain et al., 2012). Chemistry of groundwater is an important factor determining its use for domestic, irrigation and industrial purposes. Hydrogeochemical processes that are responsible for altering the chemical composition of groundwater vary with respect to space and time (Sivasubramanian et al., 2013). The hydrogeochemical processes of groundwater system help to obtain an insight into the contributions of rock/soil-water interaction (Senthilkumar \& Elango, 2013; Sivasubramanian et al., 2013). Groundwater remains the only drinking water resource in most of the High Bandama Basin rural and urban parts through several boreholes and sometimes hand pump wells or traditional wells. In fact, the high drought occurred in 1983 which led the Ivorian authorities to carry out the project of drinking in many localities. We can cite among these projects the Fund National of Hydraulic (FNH), BADEA, etc. After digging boreholes or wells, water obtained is drunk by population without knowledge of its quality. Few sources of surface water exist in the rural area (rivers, dams, source point). We denoted about 1500 dams but this water is assigned to agriculture use and sometimes fishing. Surface water is subject to variations and their sources deplete in dry period. For these reasons the authorities are focused on groundwater resources even though some boreholes levels decrease in dry season. Since groundwater is not immune to pollution and activities such as mechanized agricultural practices, rapid urbanization as well as domestic and industrial waste can pose a serious threat to groundwater potential in the basin (Gibrilla et al., 2010). The High Bandama Basin is an agricultural area. The use of agricultural inputs such as fertilizers, pesticides represent a threat for groundwater quality. Study hydrogeochemical and groundwater quality of basin become very important. In fact, groundwater quality reflects the impact of change occurs in the area. This study will seek to understand the chemical evolution of the aquifers, groundwater quality and characterize the groundwater system using hydrochemical methods such as compositional relation, cation-exchange and Gibbs diagram.

\section{Study Area}

The High Bandama Watershed (HBW) is a sub-basin of Bandama Basin. It is located at the north of Côte d'Ivoire between latitudes $8^{\circ} 40^{\prime} \mathrm{N}$ and $10^{\circ} 20^{\prime} \mathrm{N}$ and longitudes $5^{\circ} \mathrm{W}$ and $6^{\circ} 30^{\prime} \mathrm{W}$ and covered about a total area of $14,500 \mathrm{~km}^{2}$ (Figure 1). The outlet station is Tortiya and the main tributaries include rivers Lopkoho, Solomougou, Lafigué, Badénou, etc. The study area enjoys a sudanian climate with two contrast seasons: a rainy season from May to October and a dry season from November to April. The mean annual rainfall is estimated to 1230 


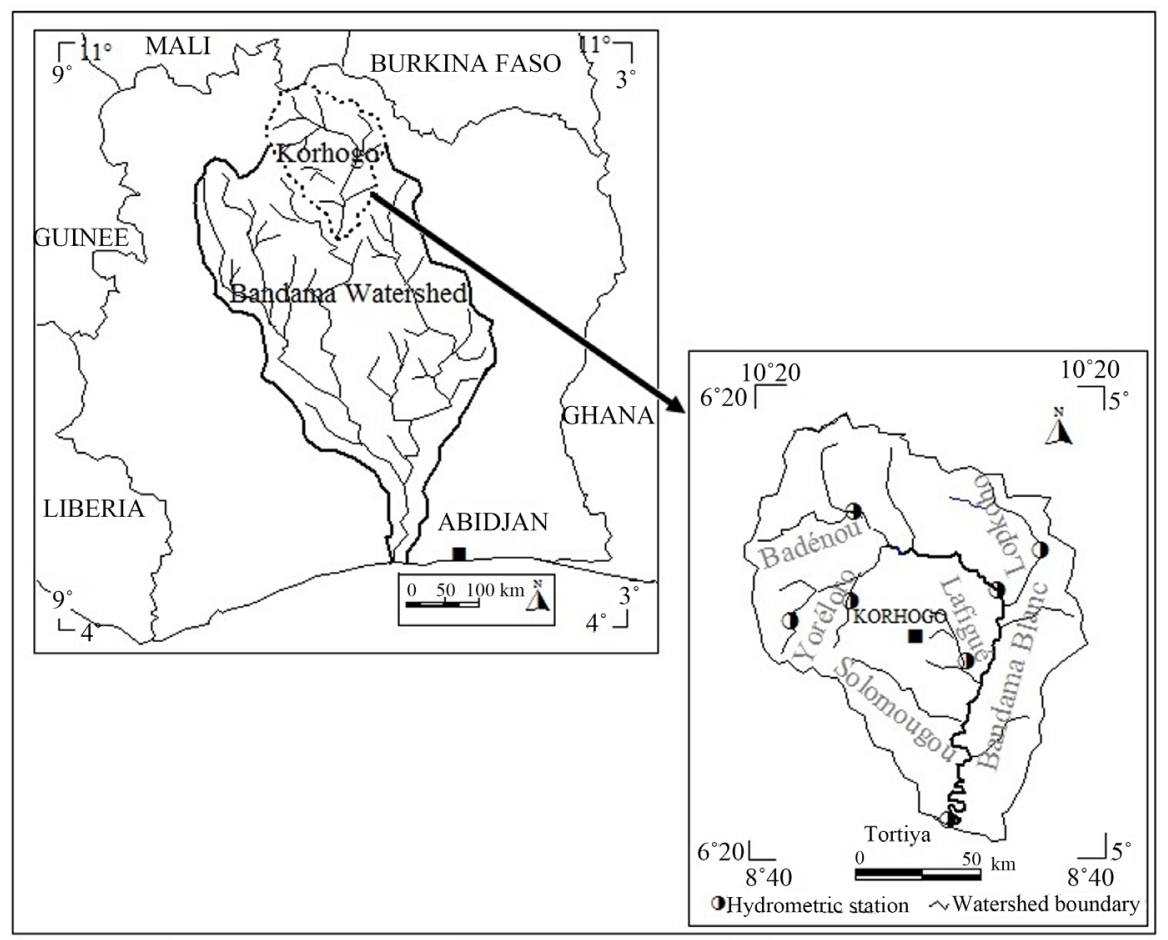

Figure 1. Location map of the study area (Soro, 2014).

mm for 1950-2000 period (Soro, 2014). Hydrologic regime is calqued on rainfall. Mean annual temperature is $26.6^{\circ} \mathrm{C}$ for $1972-2000$. However, the highest values occur in dry season with a peak on March $\left(29.5^{\circ} \mathrm{C}\right)$ and the lowest in rainy season with the minimum on August $\left(24.7^{\circ} \mathrm{C}\right.$ ) (Figure 2). Rainfall and temperature evolutions are opposite. When rainfall increases, temperature decreases. Average monthly relative humidity ranges between $35 \%$ and $79 \%$ and insolation values vary from 160.6 hours in July to 273.8 hours in January.

The basin is underlined mainly by the Lower Proterozoïc and Archean formations (Arnould, 1961). The Proterozoïc formations are divided in two parts: Eburnean complex and Birimian (Figure 3). The Eburnean consists of granitoid type with granite, granodiorite and Gabbro. The Birimian is composed of schists, greywackes, metasediments and metavulcanits. Archean formations are migmatites.

\section{Materials and Methods}

\subsection{Sample Collection}

Field samples points were selected, taking in consideration the availability of boreholes and/or wells in the area. In all, thirty-five (35) boreholes and hang-dug wells were sampled at various locations (Figure 3) in December 2012. The depth of the boreholes ranged between $30 \mathrm{~m}$ and $60 \mathrm{~m}$ and those of wells are approximately sixteen (16) to twenty (20) meters. The location of the sample points were taken with the aid of a Global Positioning System (GPS) Garmin Type 12 receiver. All the samples were collected in $0.5 \mathrm{l}$ using pre-cleaned polyethylene bottles. At first the bottles were rinsed by the spring's waters several times and 


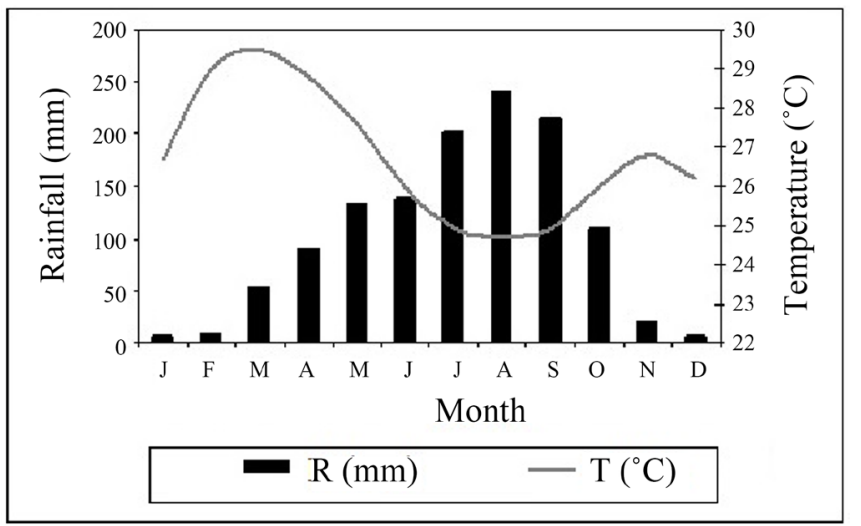

Figure 2. Ombro-thermal diagram of Korhogo synoptic station from 1972 to 2000.

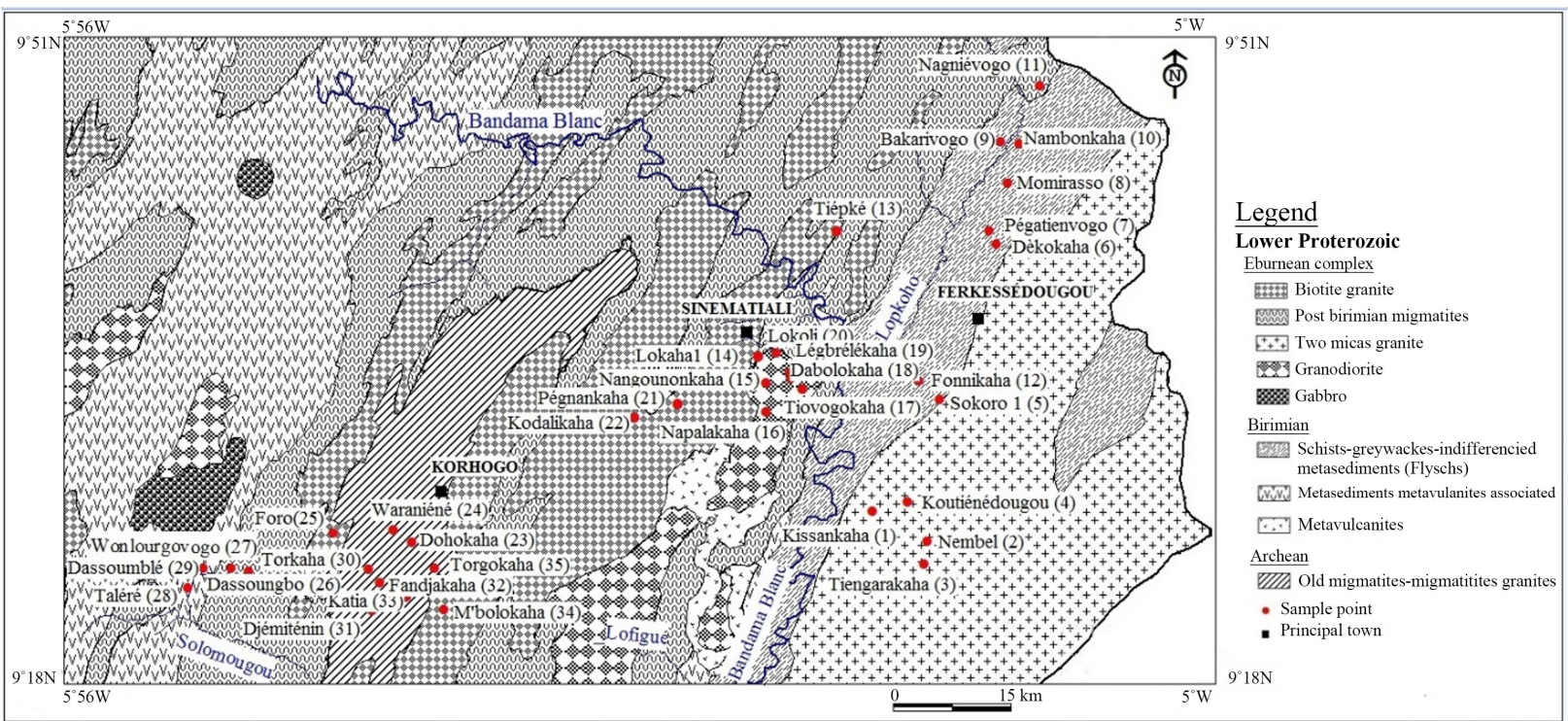

Figure 3. Map showing the sampling area and geological formations.

then collect the water. The bottles are completely filled with water to avoid air bulls. This was carried out to ensure that the samples bottles were free from contaminants. At the sampling points, the boreholes were pumped in order to purge the aquifer of stagnant water to acquire fresh aquifer water samples for analysis. Collected samples were preserved at lower temperature in an ice chest containing ice blocks and transported to laboratory in short time.

For all samples, temperature $\left(\mathrm{T}^{\circ} \mathrm{C}\right), \mathrm{pH}$, electrical conductivity $(\mathrm{EC})$ and Potential Oxidation Redox (ORP) were determined in situ. The material used is a Water Test, multi-parameters tool of HANNA type instruments serial No. 058663 which gives the four parameters cited. The absolute error for the measurement is estimated to $\pm 0.2 \mathrm{pH}$ for $\mathrm{pH}, \pm 5 \mathrm{mV}$ for potential of oxydo-reduction (ORP), \pm 2F.S for electrical conductivity and $\pm 1^{\circ} \mathrm{C}$ for temperature.

\subsection{Sample Analysis}

Major ions $\left(\mathrm{Ca}^{2+}, \mathrm{Mg}^{2+}, \mathrm{Na}^{+}, \mathrm{Cl}^{-}, \mathrm{NO}_{3}^{-}, \mathrm{HCO}_{3}^{-}\right)$were analyzed by spectropho- 
tometric method in laboratory of water chemistry of Institute National of Hygiene Public (INHP) of Abidjan using $\mathrm{HACH}$ DR5000 spectrophotometer. Whereas, $\mathrm{K}^{+}, \mathrm{SO}_{4}^{2-}$ and $\mathrm{PO}_{4}^{3-}$ were analyzed in the Center of Research Oceanology (CRO) using standard methods. The sulfates $\left(\mathrm{SO}_{4}^{2-}\right)$ were analyzed by nephelometric method. Potassium was analyzed by Atomic Absorption Spectrophotometer (AAS) and phosphates $\left(\mathrm{PO}_{4}^{3-}\right)$ by Murphy and Riley method.

\subsection{Data and Methods}

The analytical data obtained were processed for detailed geochemical study. Diagram software package was used for determining water types. It features a fully customizable database of physical and chemical parameters and it provides a comprehensive selection of analysis tools, calculations and graphs for interpreting water quality data base. Statistical parameters such as min, max, mean (average) and standard deviation (SD) were computed by using STATISTICA version 7 software. For ion exchange, we use the Chloro alkaline indices (CAI) suggest by Schoeller (1967) in Pazand \& Hezarkhani (2012). It is calculated using Equation (1):

$$
\mathrm{CAI}=\left[\mathrm{Cl}^{-}-\left(\mathrm{Na}^{+}+\mathrm{K}^{+}\right)\right] / \mathrm{Cl}^{-}
$$

where $\mathrm{Cl}, \mathrm{Na}$ and $\mathrm{K}$ concentrations are expressed in meq/l.

\section{Water Chemistry}

The analyzed ions were used to determine the process controlling the water chemistry in the basin based on Gibbs (1970) diagram. This diagram is based on three dominant processes: evaporation or crystallization, rock-dominance or weathering and precipitation. The reaction between groundwater and aquifer minerals has a significant role in groundwater quality which is useful to assume the genesis of water. The data points were plotted in this diagram and the domain where the points fall determines the dominant process. It is a graph of TDS versus $\frac{\mathrm{Na}^{+}}{\mathrm{Na}^{+}+\mathrm{Ca}^{2+}}$.

\section{Results and Discussion}

\subsection{Physico-Chemical Parameters and Groundwater Quality}

Statistical summary results of hydrochemical parameters measured in the groundwater samples collected in December 2012 are listed in Table 1. Groundwater temperature is generally low and ranges from $26.70^{\circ} \mathrm{C}$ to $30.70^{\circ} \mathrm{C}$ with an average of $28.80^{\circ} \mathrm{C}$. The $\mathrm{pH}$ of the groundwater varies from 3.20 to 6.90 and it average (mean) is 5.40. The lowest $\mathrm{pH}$ occurred at Dokaha new well and Waraniéné borehole meanwhile the highest value was obtained at Dabolokaha borehole (Sinématiali area). The WHO recommended limit for potable water is 6.5 - 9.5. About $85.7 \%$ of the samples (30) fall outside the recommended range while $14.3 \%$ fall within the range. The acidic character of groundwater is conformity to the studies carried out by Savané (1997) in Odienné region and 
Table 1. Statistical summary of the hydrochemical parameters in the study area.

\begin{tabular}{ccccc}
\hline Parameter & Minimum & Maximum & Mean & SD \\
\hline $\mathrm{T}\left({ }^{\circ} \mathrm{C}\right)$ & 26.70 & 30.7 & 28.80 & 1.01 \\
$\mathrm{pH}(\mathrm{units})$ & 3.20 & 6.90 & 5.40 & 0.95 \\
$\mathrm{EC}(\mu \mathrm{S} / \mathrm{cm})$ & 77.00 & 553.00 & 250.30 & 108.70 \\
$\mathrm{ORP}(\mathrm{mV})$ & 21.00 & 266.00 & 147.70 & 65.80 \\
$\mathrm{Ca}^{2+}(\mathrm{mg} / \mathrm{l})$ & 4.00 & 56.00 & 18.11 & 12.66 \\
$\mathrm{Mg}^{2+}(\mathrm{mg} / \mathrm{l})$ & 0.00 & 55.00 & 15.31 & 15.59 \\
$\mathrm{Na}^{+}(\mathrm{mg} / \mathrm{l})$ & 0.00 & 26.00 & 6.93 & 7.57 \\
$\mathrm{~K}^{+}(\mathrm{mg} / \mathrm{l})$ & 0.00 & 0.09 & 0.01 & 0.02 \\
$\mathrm{NH}_{4}^{+}(\mathrm{mg} / \mathrm{l})$ & 0.00 & 0.06 & 0.01 & 0.01 \\
$\mathrm{HCO}_{3}^{-}(\mathrm{mg} / \mathrm{l})$ & 5.00 & 215.00 & 77.00 & 49.19 \\
$\mathrm{Cl}^{-}(\mathrm{mg} / \mathrm{l})$ & 0.00 & 38.00 & 10.77 & 11.66 \\
$\mathrm{SO}_{4}^{2-}(\mathrm{mg} / \mathrm{l})$ & 0.60 & 47.24 & 9.70 & 11.80 \\
$\mathrm{PO}_{4}^{3-} \quad(\mathrm{mg} / \mathrm{l})$ & 0.01 & 0.21 & 0.05 & 0.06 \\
$\mathrm{NO}_{3}^{-}(\mathrm{mg} / \mathrm{l})$ & 0.16 & 36.00 & 13.91 & 12.91 \\
\hline
\end{tabular}

those of Faillat \& Blavoux (1989) on ivorian fractured aquifers. These latter authors indicate that the $\mathrm{pH}$ values can decrease to 4 seek 3 in Côte d'Ivoire fissures aquifers. Acidic character of groundwater may be lied to excess quantity of free $\mathrm{CO}_{2}$ present in the soil or to the water flow on substances called permutolits releasing the $\mathrm{H}^{+}$ions (Jourda, 1987; Soro, 1987; Tapsoba-Sy, 1995; Oga, 1998).

One of the most effects of acidification of groundwater is corrosion. Acid groundwater can corrode plumbing system and solubilize metals in the soil or in the plumbing systems (Bertills \& Bertil, 1995). According the studies of Knutsson (1994), the corrosion will also increase the copper content in drinking water, which may be a risk to the human health: infant diarrhea is suspected when the copper content in tap water exceeds $1 \mathrm{mg} \mathrm{Cu}^{-1}$ and fatal liver cirrhosis has been observed as an effect of elevated copper content in drinking water in several countries, for example Germany (Oskarsson \& Strinnö, 1990) and India (Bhave et al., 1987).

Electrical conductivity (EC) values were generally low. Minimum and maximum values were respectively $77 \mu \mathrm{S} / \mathrm{cm}$ and $553 \mu \mathrm{S} / \mathrm{cm}$ with the mean value of $250.3 \mu \mathrm{S} / \mathrm{cm}$. Major cations $\left(\mathrm{Ca}^{2+}, \mathrm{Mg}^{2+}, \mathrm{Na}^{+}\right.$and $\left.\mathrm{K}^{+}\right)$were also generally low with $\mathrm{Ca}^{2+}$ and $\mathrm{Mg}^{2+}$ being the most dominants. $\mathrm{Ca}^{2+}$ and $\mathrm{Mg}^{2+}$ concentration ranges from $4-56 \mathrm{mg} / \mathrm{l}$ and $0-55 \mathrm{mg} / \mathrm{l}$ respectively with mean value of 18.11 and $15.31 \mathrm{mg} / \mathrm{l}$. Bicarbonate $\left(\mathrm{HCO}_{3}^{-}\right)$is the most dominant anion with minimum and maximum values ranging from 5 to $215 \mathrm{mg} / \mathrm{l}$.

The nitrate in the groundwater varied from $0.16-36 \mathrm{mg} / \mathrm{l}$ with a mean of $13.91 \mathrm{mg} / \mathrm{l}$. These values don't exceed the drinking water guideline value of 50 $\mathrm{mg} / \mathrm{l}$ according WHO. Even though it has been observed that igneous rocks 
contain small amounts of nitrate (Daviest \& Dewiest, 1966) cited by Gibrilla et al. (2010), most nitrate in water comes probably from fertilizers, nitrification by leguminous plants and animal excreta. Nitrogen is an essential component of protein hence occurs in all living organisms. When these material decay through microbial activities, the complex protein changes through amino acid to ammonia, nitrite and finally nitrate. The nitrate produced may leach the groundwater. Nitrate ion concentration in excess in drinking water creates several problems (Mishra et al., 2005) in Ghislain et al. (2012) like cyanosis, tumors goiter, oral cancer, lymphoma and dispnea. Nitrate contaminated water supplies carries the risk of methaemoglobinaemia (blue-baby syndrome) and stomach cancer. The main pollution risk for the aquifers is vertical infiltration of precipitation and flushing of pollutants from the soil. $\mathrm{NH}_{4}^{+}$and $\mathrm{PO}_{4}^{3-}$ were observed to have generally low concentration ranging from $0-0.06 \mathrm{mg} / \mathrm{l}$ and $0.01-0.21 \mathrm{mg} / \mathrm{l} \mathrm{re}$ spectively.

\subsection{Hydrochemical Facies}

Groundwater samples are grouped into facies depending on the dominant ions present. The Piper trilinear plot of groundwater is shown in Figure 4. The majority of the groundwater samples including boreholes (F), modern well (PM) and traditional well (PT) on the study area are characterized by $\mathrm{Ca}-\mathrm{HCO}_{3}$ (48.57\%) or $\mathrm{Ca}-\mathrm{Mg}-\mathrm{HCO}_{3}$ (31.43\%) water type. Near, the second group which occupies about $17.14 \%$ of the samples is $\mathrm{Ca}-\mathrm{Mg}-\mathrm{Cl}$ water type. One sample $\left(\mathrm{n}^{\circ}\right.$ 22) corresponding to traditional well is $\mathrm{Na}-\mathrm{Cl}$ water type.

In general, the study area groundwater is bicarbonate $\left(\mathrm{HCO}_{3}\right)$ type. This result is similar to those of many researchers like Biémi (1992), Soro (1987, 2002),

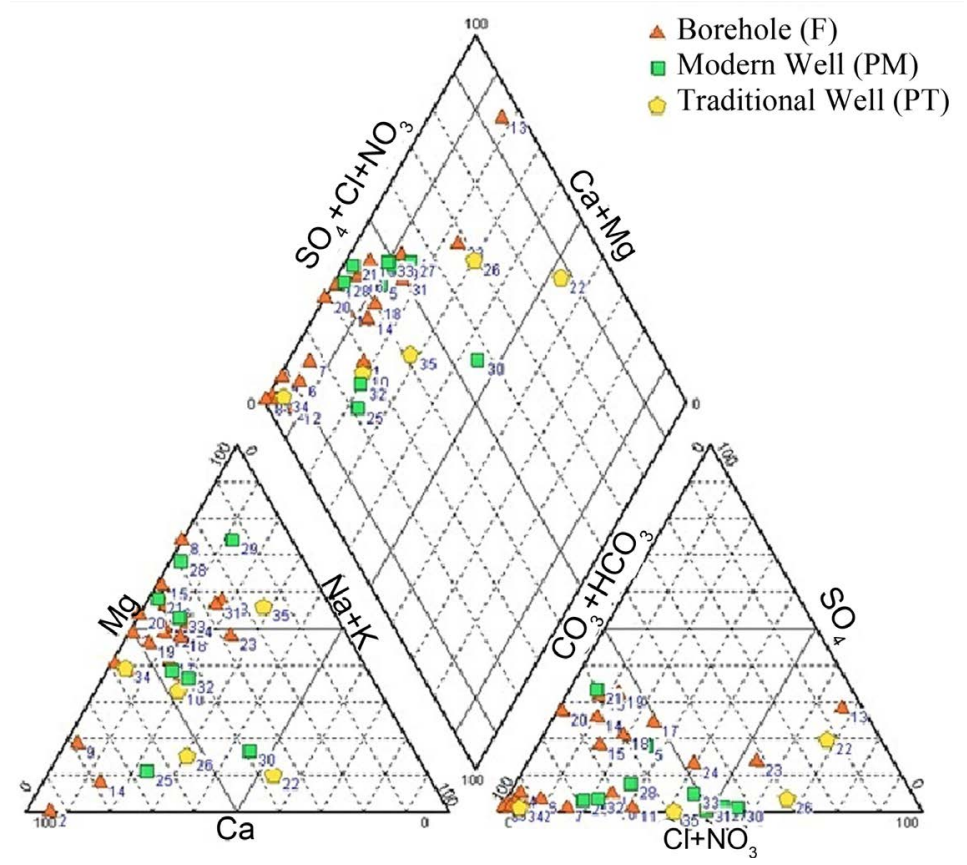

Figure 4. Piper plot for the groundwater samples of High Bandama Watershed. 
Faillat \& Blavoux (1989) who are noted the dominance of $\mathrm{HCO}_{3}$ ion in hard rock terrain of Côte d'Ivoire. Some similar results are been obtained in Burkina Faso by Yameogo (2008).

\subsection{Hydrochemical Processes}

\section{- Compositional Relation}

Since $\mathrm{Ca}^{2+}, \mathrm{Mg}^{2+}, \mathrm{Na}^{+}, \mathrm{K}^{+}, \mathrm{HCO}_{3}^{-}, \mathrm{Cl}^{-}, \mathrm{SO}_{4}^{2-}, \mathrm{NO}_{3}^{-}$are the observed solutes in the groundwater, an examination is made using relation between ions to account for their sources or origin. The chemical data of the groundwater samples are plotted on $\mathrm{Ca}^{2+}+\mathrm{Mg}^{2+}$ versus $\mathrm{HCO}_{3}^{-}+\mathrm{SO}_{4}^{2-}$ (Figure 5). In fact, the plot of $\mathrm{Ca}+\mathrm{Mg}$ versus $\mathrm{SO}_{4}+\mathrm{HCO}_{3}$ is a major indicator to identify ion exchange process activated in the study area (Srinivasamoorthy et al., 2008). The majority of samples fall above the equiline (1:1) (black line) indicating predominance of alkali earth or excess calcium and magnesium in groundwater exchanged with sodium from aquifers materials. Netherveless, some samples fall in $\mathrm{HCO}_{3}+\mathrm{SO}_{4}$ indicating the ion exchanges process which may be due to excess bicarbonate (Figure 5).
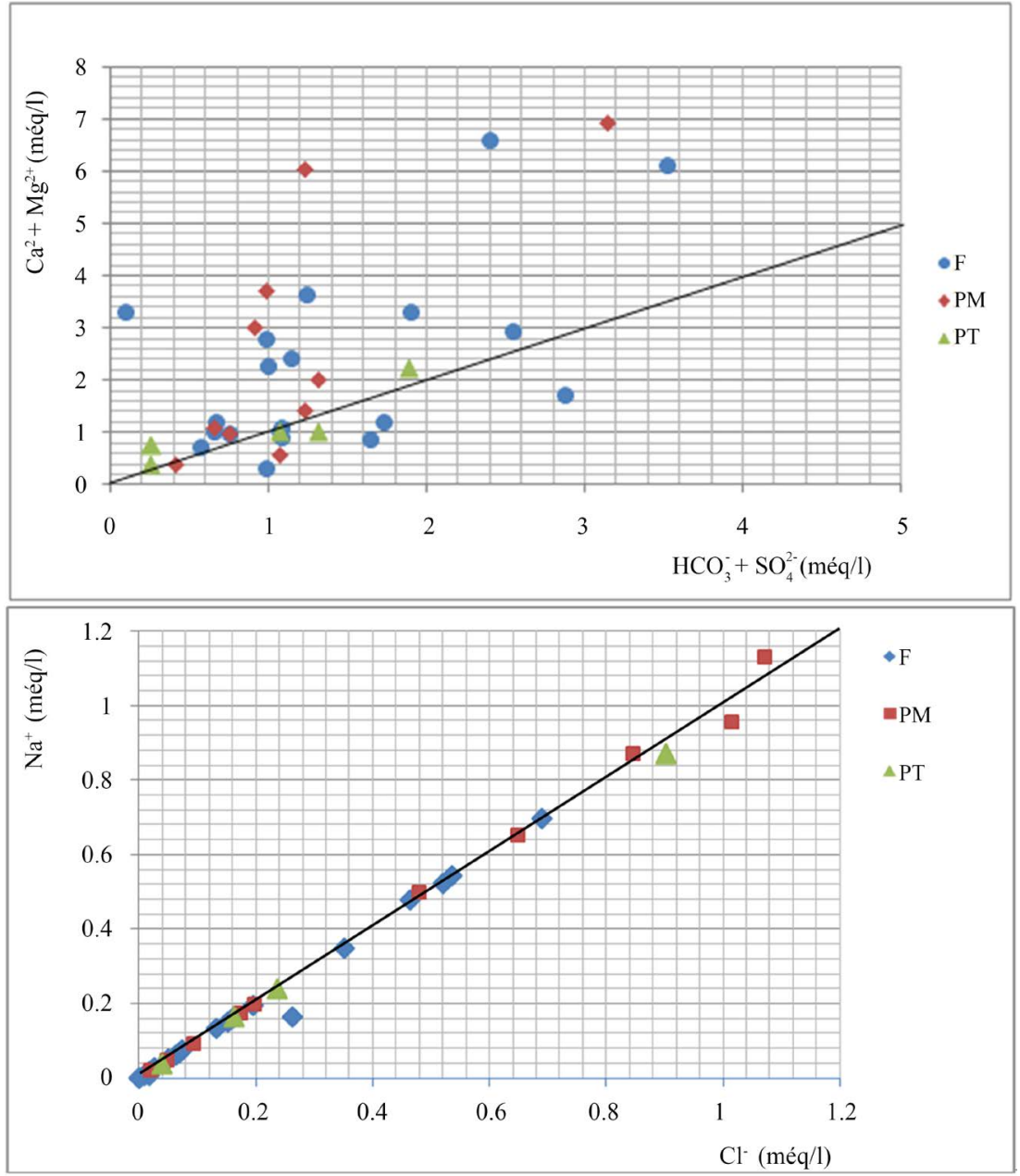

Figure 5. Relationship between $\mathrm{Ca}+\mathrm{Mg}$ vs $\mathrm{HCO}_{3}+\mathrm{SO}_{4}$ and $\mathrm{Na}$ vs $\mathrm{Cl}$. 
The plot for $\mathrm{Na}$ versus $\mathrm{Cl}$ (Figure 5) shows that majority of samples fall on the equiline (1:1). The $\mathrm{Na} / \mathrm{Cl}$ relationship has often been used to identify the mechanism for acquiring salinity and saline intrusion (Sivasubramanian et al., 2013). Sodium and chloride show a good correlation indicating groundwater are probably controlled by water-rock interaction. But for some authors like Li et al. (2018), when $\mathrm{Na} / \mathrm{Cl}$ molar ratio is approximately equal to 1 , it means that $\mathrm{Na}$ and $\mathrm{Cl}$ come from halite $(\mathrm{NaCl})$, whereas a ratio greater than one is commonly interpreted as $\mathrm{Na}$ release from a reaction during silicate weathering. But $\mathrm{Na}$ and $\mathrm{Cl}$ may have some other source. According the study of Sako et al. (2018) in the northwestern Burkina Faso, atmospheric deposition (dust and rainfall) and decomposition of organic matter may be a source of $\mathrm{Cl}$.

- Cation-exchange

Figure 6 shows the distribution of Chloro alkaline indices (CAI) in the study area. The majority of samples (66.67\%) show negative values for indices whereas $33.33 \%$ are positive values. When the indices are positive, we talk about direct exchange and indirect exchange in opposite case. Positive indices mean that $\mathrm{Na}$ and $\mathrm{K}$ from groundwater are exchanged with $\mathrm{Ca}$ and $\mathrm{Mg}$ from the host rock. Most samples with negatives indices suggest that $\mathrm{Ca}$ and $\mathrm{Mg}$ from the groundwater are exchanged with $\mathrm{Na}$ and $\mathrm{K}$ from host rock.

- Gibbs diagram

In additional to Piper diagram and compositional relation, Gibbs diagram was also used to gain better insight into hydrochemical processes such as precipitation, rock-water interaction and evaporation on groundwater chemistry in the study area (Figure 7). The graph of TDS versus $\frac{\mathrm{Na}^{+}}{\mathrm{Na}^{+}+\mathrm{Ca}^{2+}}$ for the 35 data points indicates that groundwater within the watershed is located within the rock weathering field. This suggests that weathering and subsequent dissolution of the minerals present in the groundwater is the dominant process in the study area. In other term, it means that precipitation induced chemical weathering along with disso lution of rock forming minerals. In the literature, there are

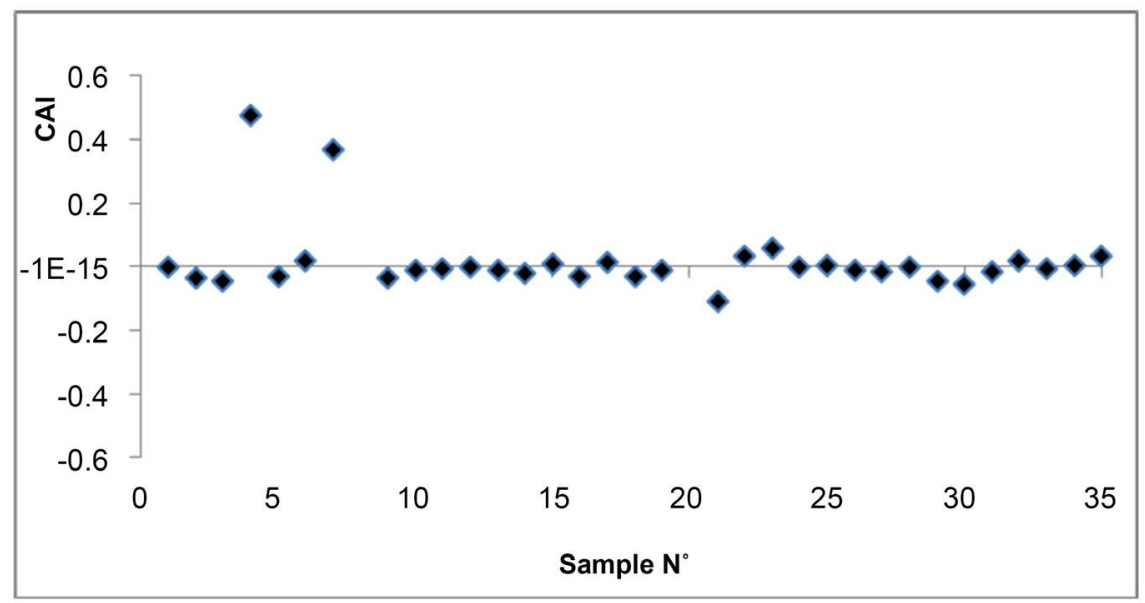

Figure 6. Distribution of Chloro alkaline indices (CAI) in the study area. 


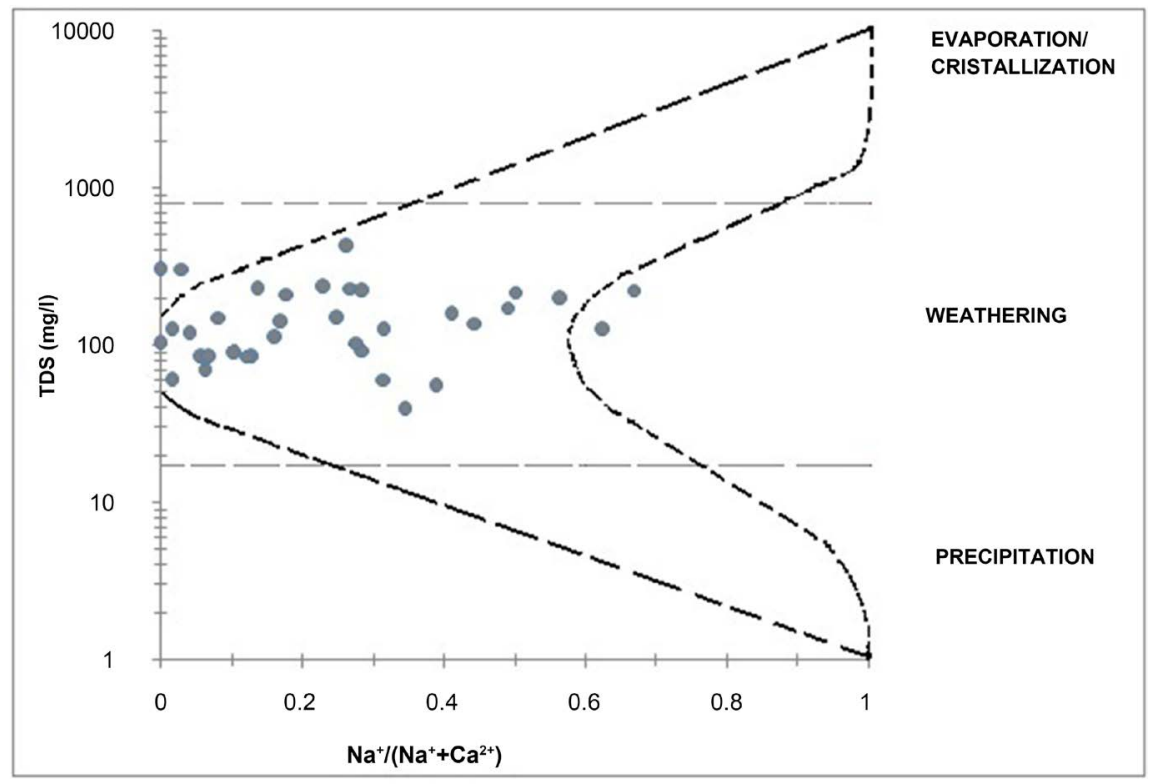

Figure 7. Mechanism controlling groundwater chemistry in the study area.

many types of Gibbs diagram. Aghazadeh et al. (2017), Adimalla \& Venkatayogi (2018) used Gibbs diagram forms TDS versus $(\mathrm{Na}+\mathrm{K}) /(\mathrm{Na}+\mathrm{K}+\mathrm{Ca})$ and TDS versus $\mathrm{Cl} /\left(\mathrm{Cl}+\mathrm{HCO}_{3}\right)$ to determine respectively mechanisms governing groundwater chemistry in the Ardabil area, a city in northwest of Iran and the groundwater chemistry evolution in semi-arid region of Basara, Telangana in south India. Their study reveals that weathering of rock (rock dominance) is the main control of groundwater chemistry. Moreover, Aghazadeh et al. (2017) show also in some of samples evaporation is influencing groundwater quality.

\section{Conclusion}

This study investigated the physico-chemical properties of the groundwater to understand the status of water quality and also the ions sources. The groundwater is acidic with $\mathrm{pH}$ values ranges from 3.20 to 6.90 and an average of 5.40. Electrical conductivity (EC) values were generally low. Minimum and maximum values were respectively $77 \mu \mathrm{S} / \mathrm{cm}$ and $553 \mu \mathrm{S} / \mathrm{cm}$ with the mean value of 250.3 $\mu \mathrm{S} / \mathrm{cm}$. Major cations $\left(\mathrm{Ca}^{2+}, \mathrm{Mg}^{2+}, \mathrm{Na}^{+}\right.$and $\left.\mathrm{K}^{+}\right)$were also generally low. $\mathrm{Ca}^{2+}$ and $\mathrm{Mg}^{2+}$ are being the most dominants cations with concentration values ranges from $4-56 \mathrm{mg} / \mathrm{l}$ and $0-55 \mathrm{mg} / \mathrm{l}$ respectively with mean value of 18.11 and 15.31 $\mathrm{mg} / \mathrm{l}$. Bicarbonate $\left(\mathrm{HCO}_{3}^{-}\right)$is the most dominant anion with minimum and maximum values ranging from 5 to $215 \mathrm{mg} / \mathrm{l}$. In general, all parameters values are within the WHO guideline values and groundwater quality is good for drinking.

Four types of water were identified which are $\mathrm{Ca}-\mathrm{HCO}_{3}$ (48.57\%), Ca-Mg- $-\mathrm{HCO}_{3}$ (31.43\%), Ca-Mg-Cl (17.14\%) and $\mathrm{Na}-\mathrm{Cl}(2.86 \%)$ in which $\mathrm{Na}-\mathrm{Cl}$ type was observed in one sample. The study area groundwater is generally bicarbonate $\left(\mathrm{HCO}_{3}\right)$ type. Compositional relation carried out by plots of $\mathrm{Ca}+\mathrm{Mg}$ versus 
$\mathrm{HCO}_{3}+\mathrm{SO}_{4}$ and $\mathrm{Na}$ versus $\mathrm{Cl}$ showed that excess of $\mathrm{Ca}$ and $\mathrm{Mg}$ from groundwater is exchanged with $\mathrm{Na}$ and $\mathrm{K}$ from aquifer materials. The calculation of Chloro Alkaline Indice (CAI) confirms the results of $\mathrm{Ca}+\mathrm{Mg}$ versus $\mathrm{HCO}_{3}+$ $\mathrm{SO}_{4}$ plot. It shows that the majority of groundwater samples (66.67\%) with negative values of CAI exchange their ions $\mathrm{Ca}$ and $\mathrm{Mg}$ with the ions $\mathrm{Na}$ and $\mathrm{K}$ from host rock. In reverse, $33.33 \%$ of groundwater samples are exchanged their ion $\mathrm{Na}$ and $\mathrm{K}$ with ions $\mathrm{Ca}$ and $\mathrm{Mg}$ from aquifer materials.

Gibbs diagram demonstrates that weathering or rock dominance is the dominant process responsible of water chemistry in the study area. Further investigation on the rock-water interaction was indicated the dominance of silicate weathering on the other processes in contributing the ions such as $\mathrm{Na}, \mathrm{Ca}, \mathrm{Mg}$, $\mathrm{HCO}_{3}$, etc. This study provides a baseline for the groundwater chemistry in the High Bandama region.

\section{Conflicts of Interest}

The authors declare no conflicts of interest regarding the publication of this paper.

\section{References}

Adimalla, \& Venkatayogi (2018). Geochemical Characterization and Evaluation of Groundwater Suitability for Domestic and Agricultural Utility in Semi-Arid Region of Basara, Telangana State, South India. Applied Water Science, 8, 44.

Aghazadeh, N., Chitsazam, M., \& Golestan, Y. (2017). Hydrochemistry and Quality Assessment of Groundwater in the Ardabil Area, Iran. Applied Water Science, 7, 35993616. https://doi.org/10.1007/s13201-016-0498-9

Arnould, M. (1961). Étude géologique des migmatiques et des granites précambriens du Nord-Est de la Côte d'Ivoire et de la Haute-Volta méridionale. Bulletin de la direction de la géologie et de la prospection minière No. 3 (175 p). Abidjan: Direction de la géologie et de la prospection minière.

Bertills, U., \& Bertil, S. (1995). Methods for Treating Acid Groundwater Results and Evaluation of Long-Term Tests. Water Air and Soil Pollution, 85, 1849-1854.

https://doi.org/10.1007/BF00477249

Bhave, S. A., Pandit, A. N., \& Tanner, M. S. (1987). Comparison of Feeding History of Children with Indian Childhood Cirrhosis and Paired Controls. Journal of Pediatric Gastroenterology and Nutrition, 562-567.

https://doi.org/10.1097/00005176-198707000-00013

Biémi, J. (1992). Contribution à l'étude géologique, hydrogéologique et par télédétection des bassins versants subsaheliens du socle précambrien d'Afrique de l'Ouest: Hydrostructurale, hydrodynamique, hydrochimie et isotopie des aquifères discontinus de sillons et aires granitiques de la Haute Marahoué (Côte d'Ivoire) (493 p). Thèse de Doctorat d'Etat ès Sciences Naturelles, Université Nationale d'Abidjan.

Daviest, S. N., \& Dewiest, R. J. M. (1966). Hydrogeology. New York: John Willey and Sons, 463.

Faillat, J. P., \& Blavoux, B. (1989). Caractères hydrochimiques des nappes des roches endogènes fissurées en zone tropicale humide: L'exemple de la Côte d'Ivoire. Journal of African Earth Sciences, 9, 31-40. https://doi.org/10.1016/0899-5362(89)90005-5 
Ghislain, T. Y. J., Feumba, R., Wethe, J., Ekodeck, G. E., \& De Marsily, G. (2012). Evaluation of Groundwater Suitability for Domestic and Irrigation Purposes: A Case Study from Mingoa River Basin, Yaounde, Cameroon. Journal of Water Resource and Protection, 4, 285-293. https://doi.org/10.4236/jwarp.2012.45031

Gibbs, R. J. (1970). Mechanisms Controlling World Water Chemistry. Science, 17, 10881090. https://doi.org/10.1126/science.170.3962.1088

Gibrilla, A., Osae, S., Akiti, T. T., Adomako, D., Ganyaglo, S. Y., Bam, E. P. K., \& Hadisu, A. (2010). Hydrogeochemical and Groundwater Quality Studies in the Northern Part of the Densu River Basin of Ghana. Journal of Water Resources and Protection, 2, 1071-1081. https://doi.org/10.4236/jwarp.2010.212126

Jourda, J. P. R. (1987). Contribution à l'étude géologique et hydrogéologique de la région du Grand Abidjan (Côte d'Ivoire) (317 p). Thèse de Doctorat $3^{\text {ème }}$ Cycle, Université de Grenoble I, Institut Dolomieu.

Knutsson, G. (1994). Acidification Effects on Groundwater-Prognosis of the Risks for Future. IAHS Publication No. 222.

Li, X., Wu, H., Qian, H., \& Gao, Y. (2018). Groundwater Chemistry Regulated by Hydrochemical Processes and Geological Structures: A Case Study in Tongchuan, China. Water, 10, 338. https://doi.org/10.3390/w10030338

Mishra, P. C., Behera, P. C., \& Patel, R. K. (2005). Contamination of Water Due to Major Industries and Open Refuse Dumping in the Steel City of Orissa-A Case Study. Journal of Environmental Science and Engineering, 47, 141-154.

Oga, Y. M. S. (1998). Ressources en eaux souterraines dans la région du Grand-Abidjan (Côte d'Ivoire). Approche hydrochimique et isotopique (240 p). Thèse Unique de Doctorat, Université de Paris-Sud Orsay.

Oskarsson, A., \& Strinnö, M. (1990). Kan koppar orsaka letal levercirros spädbarn i Sverige? Läkartidningen, 87, 1243-1246.

Pazand, K., \& Hezarkhani, A. (2012). Investigation of Hydrochemical Characteristics of Groundwater in the Bukan Basin, Northwest of Iran. Applied Water Science, 2, 309-315.

Sako, A., Yaro, J. M., \& Bamba, O. (2018). Impacts of Hydrogeochemical Processes and Anthropogenic Activities on Groundwater Quality in the Upper Precambrian Sedimentary Aquifer of Northwestern Burkina Faso. Applied Water Science, 8, 88. https://doi.org/10.1007/s13201-018-0735-5

Savané, I. (1997). Contribution à l'étude géologique et hydrogéologique des aquifères discontinus du socle cristallin d'Odienné (Nord-Ouest de la Côte d'Ivoire). Apports de la télédétection et d'un Système d'Information Hydrogéologique à Référence Spatiale (386 p). Thèse de Doctorat d'Etat èS Sciences Naturelles, Université d'Abidjan.

Schoeller, H. (1967). Qualitative Evaluation of Groundwater Resources. In Methods and Technics of Groundwater Investigation and Development (pp. 44-52). Water Resource Series No. 33, Paris: UNESCO.

Senthilkumar, M., \& Elango, L. (2013). Geochemical Processes Controlling the Groundwater Quality in Lower Palar River Basin, Southern India. Journal of the Geological Society of India, 78, 523-540.

Sivasubramanian, P., Balasubramanian, N., Soundranayagam, J. P., \& Chandrasekar, N. (2013). Hydrochemical Characteristics of Coastal Aquifers of Kadaladi, Ramanathapuram District, Tamilnadu, India. Applied Water Science, 3, 603-612.

Soro, N. (1987). Contribution à l'étude géologique et hydrogéologique du Sud-Est de la Côte d'Ivoire: Bassin versant de la Mé(239 p). Thèse de Doctorat $3^{\grave{e}}$ cycle, Université de 
Grenoble 1, Institut Dolomieu.

Soro, N. (2002). Hydrochimie et Géochimie isotopique des eaux souterraines du degré carré de Grand-Lahou et ses environs (Sud-Ouest de la Côte d'Ivoire). Implications hydrologiques et hydrogéologiques (256 p). Thèse d'Etat ès-Sciences Naturelles, Université de Cocody.

Soro, T. D. (2014). Evolution des ressources en eau du bassin versant du Haut Bandama à Tortiya (Nord de la Côte d'Ivoire) dans un contexte de variabilité et de changement climatiques: Impacts hydrologiques, hydrogéologiques et hydrochimiques (243 p). Thèse de Doctorat, Université Félix Houphouët-Boigny de Cocody-Abidjan, Côte d'Ivoire.

Srinivasamoorthy, K., Chidambaram, S., Prasanna, M. V., Vasanthavihard, P. J., \& Anandhan, P. (2008). Identification of Major Sources Controlling Groundwater Chemistry from a Hard Rock Terrain-A Case Study from Mettur Taluk, Salem District, Tamil Nadu, India. Journal of Earth System Science, 117, 49-58.

https://doi.org/10.1007/s12040-008-0012-3

Tapsoba-Sy, A. (1995). Contribution à l'étude géologique et hydrogéologique de la région de Dabou (Sud de la Côte d'Ivoire): Hydrochimie, isotopie et indice cationique de vieillissement des eaux souterraines $\left(200\right.$ p). Thèse de Doctorat $3^{\text {è }}$ cycle, Université Nationale de Côte d'Ivoire.

Yameogo, S. (2008). Ressource en eau souterraine du centre urbain de Ouagadougou au Burkina Faso. Qualité et vulnérabilité (245 p). Thèse Unique de Doctorat, Université d'Avignon et des Pays de Vaucluse. 